\title{
NEAR STOICHIOMETRIC, IRREVERSIBLE INACTIVATION OF BACTERIAL COLLAGENASES BY O-CHLORANIL $(3,4,5,6$-TETRACHLORO- 1,2-BENZOQUINONE)
}

Pirkko-Liisa Makinen and Kauko K. Makinen

Department of Biologic and Materials Sciences, School of Dentistry, The University of Michigan, Ann Arbor, MI 48109

Received March 14, 1988

SUMMARY: The hydrogen-abstracting quinone derivative $3,4,5,6-$ tetrachloro-1,2-benzoquinone (o-chloranil) caused a strong, near stoichiometric, irreversible inactivation of the collagenases from Bacillus cereus, Clostridium histolyticum and Achromobacter iophagus. p-Chloranil was a weaker inactivator. o-chloranil reacted rapidly with a site that affected substrate binding. Amino acid analyses of native and totally inactivated enzymes, and the pH-profile of inactivation suggest that the dissociated form of a tyrosine residue was modified. $\odot 1988$ Acadenic Press, Inc.

INTRODUCTION: 으A is a purple crystalline substance sparingly soluble in water and easily soluble in several organic solvents. The term "chloranil" used in organic chemistry normally means p$\mathrm{CA}$; most earlier studies concerned this quinone. p-CA is a strong electron acceptor $(1,2)$. It reacts with primary and secondary arylamines, amino acids, phenols, pyrrole, naphthalene (3-7), cycloserine (8), tranexamic acid (9), and was used in the assay of proteolytic activity (10). Charge-transfer interactions between $\mathrm{p}-\mathrm{CA}$ and amino acids $(11-14)$ and $\mathrm{p}-\mathrm{CA}$ and proteins (11) have been studied. Although p-CA and $\underline{0}-C A$ are distinctly different compounds, they share several general properties of quinones. only o-CA has been investigated as an enzyme inhibitor: 을 bound to liver glutathione s-transferase (15);

\footnotetext{
Abbreviations used: ㅇ-CA, o-Chloranil; p-CA, p-chloranil; TNBS, 2,4,6-trinitrobenzenesulfonic acid; PZ-PLGPA, phenylazobenzyloxycarbonyl-L-prolyl-L-leucylglycyl-L-prolyl-D-arginine; DDQ, 2,3dichloro-5,6-dicyano-1,4-benzoquinone; ㅇ-BQ, ㅇ-benzoquinone.
} 
no chemical or mechanistic information about this reaction was given. We report in this paper totally new findings showing that these CAs, and especially o-CA, can be used as extremely fast, effective and irreversible inactivators of bacterial collagenases.

MATERIALS AND METHODS: o-CA, p-CA, p-chloranilic acid, DDQ, poly-L-lysine, PZ-PLGPA and clostridium histolyticum collagenase (Type VII) were obtained from Sigma Chemical company. Achromobacter iophagus collagenase was from Boehringer Mannheim and the Bacillus cereus collagenase was purified as previously described (16). Streptococcus faecalis collagenolytic endopeptidase was purified at this laboratory.

Crystalline o-CA was dissolved in absolute ethanol and was always used immediately. Appropriate ethanol controls were included. The inactivation of the enzymes by o-CA did not depend on photosensitized reactions; all subsequent experiments were thus conducted in regular laboratory lighting (about 1,200 1x) at $22^{\circ} \mathrm{C}$. Normally, 1-10 $\mu 1$ aliquots of $0.22 \mathrm{mM}$ o-CA were added to 1.0-ml buffered enzyme solutions and the effect of the reagent was determined by removing $10-\mu l$ aliquots from the modification mixture to enzyme assay mixtures. Phosphate buffer was found to be most suitable. In this procedure the o-CA was diluted so effectively that it had no effect on the rate of hydrolysis of PZ-PLGPA. Experiments with p-CA, DDQ and p-chloranilic acid were conducted as above. Collagenase activity was determined at $30^{\circ} \mathrm{C}$ using PZ-PLGPA as substrate $(16,17)$.

RESULTS: Unless otherwise stated, the results shown below were obtained with the B. cereus collagenase. Inactivation of the collagenases by ㅇ-CA was time-, concentration- and pH-dependent. For example, at an enzyme to o-CA ratio of $3: 1$, the enzyme was inactivated by $21 \%$ in $10 \mathrm{~min}$, but this low concentration of $\mathrm{o}-\mathrm{CA}$ $(\sim 0.09 \mu \mathrm{M})$, was expectedly too low for complete inactivation (Fig. 1A). When the enzyme:o-CA ratio was 1.04 , the inactivation was $35 \%$ and $62 \%$ in $10 \mathrm{~min}$ and $20 \mathrm{~min}$, respectively. The dependence of the apparent rate constant of inactivation on [oCA] is shown in Fig. 1B. The process was irreversible; it was not possible to restore the enzyme activity thorough dialysis or by diluting the modification mixture. Under conditions where oCA caused a total inactivation of the collagenase, p-CA and DDQ inactivated at most by $7 \%$ and p-chloranilic acid by $5 \%$. The $B$. 


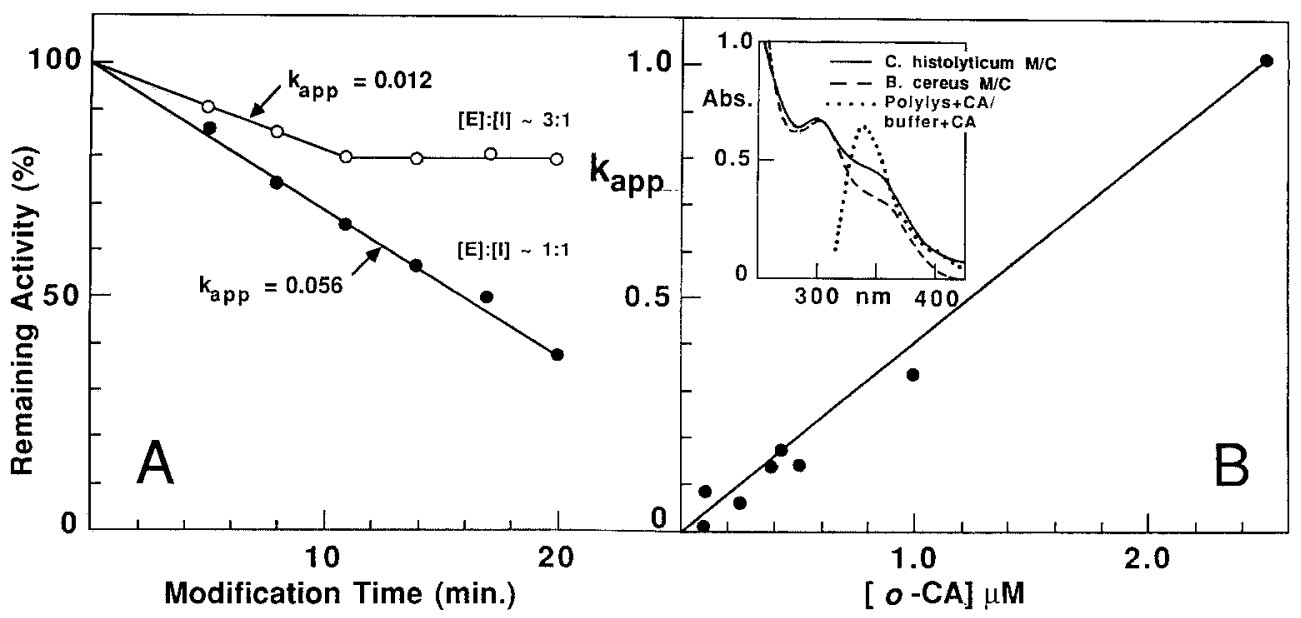

Fig. 1. Inactivation of B. cereus collagenase by o-CA in $20 \mathrm{mM}$ phosphate buffer ( $\mathrm{pH} 8.0$ ) at $30^{\circ} \mathrm{C}$ (A) and dependence of the apparent inactivation constant on [o-CA] (B). Inset: Difference spectra between fully inactivated $(\bar{M})$ and native $(C)$ enzymes, and between modified and unmodified poly-L-lysine.

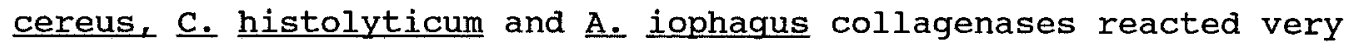
similarly with o-CA. The str. faecalis enzyme was also strongly inactivated by $\mathrm{o}-\mathrm{CA}$. Although our results suggest a $1: 1$ reaction between 으-CA and collagenase, the lability of 으-CA may prevent stoichiometry under certain conditions.

The rate of inactivation increased with increasing $\mathrm{pH}$ (Fig. $2 \mathrm{~A}$; the enzyme was stable at the $\mathrm{pH}$ values indicated). $1 \mathrm{mM}$ TNBS, a reagent of protein amino groups (18-20), almost fully protected the enzyme against o-CA-induced inactivation (Fig. 2B). For this reason, the absorption spectra between ㅇ-CA-treated and untreated poly-L-lysine were determined. In aqueous solutions, the reaction with poly-L-lysine gave a maximum at $340 \mathrm{~nm}$ (Fig. 1B inset). The difference spectra between o-CA-treated and unmodified enzymes revealed maxima at $305 \mathrm{~nm}$ and at 340-350 nm. Because the modified enzymes were thoroughly dialyzed, the maximum at $305 \mathrm{~nm}$ was considered to result from irreversible binding of o-CA (or its reaction product) to protein. Treatment of the inactivated enzymes overnight at $+4^{\circ} \mathrm{C}$ with $0.1 \mathrm{M}$ 


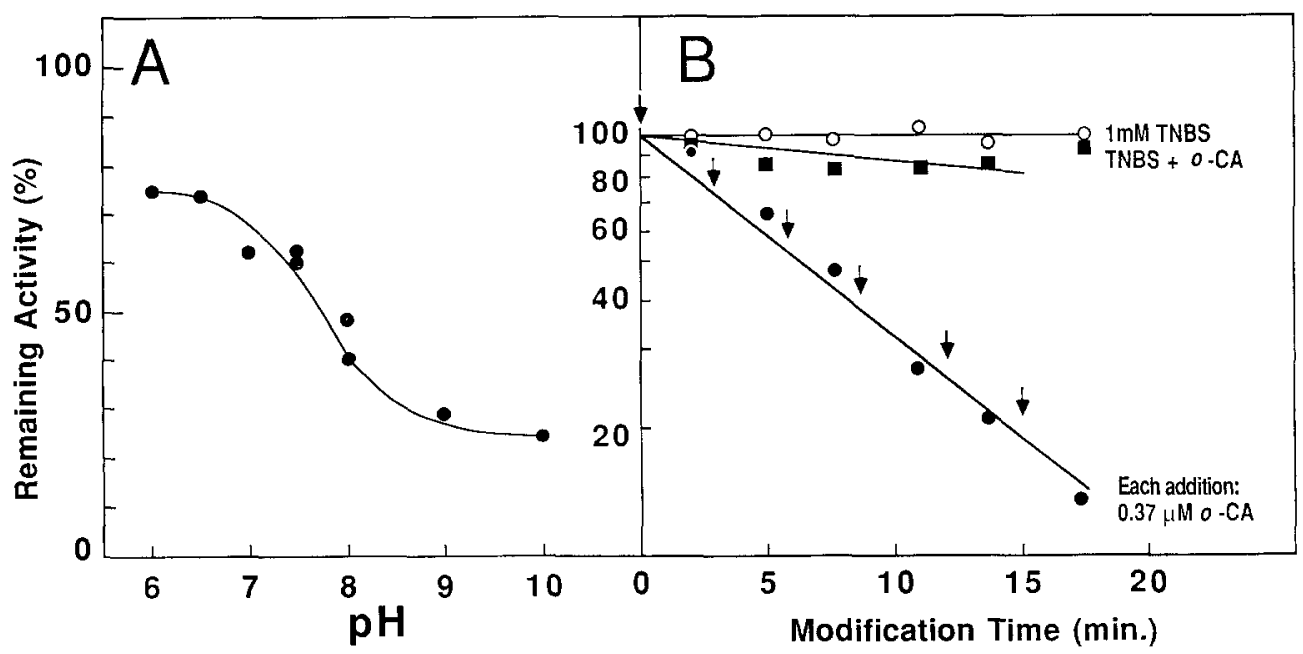

Fig. 2. Dependence of the degree of inactivation of $B$. cereus collagenase by o- $\mathrm{CA}$ on $\mathrm{pH}$ (A). Aliquots of the enzyme were treated for $5 \mathrm{~min}$ at $30^{\circ} \mathrm{C}$ in $0.1 \mathrm{M} \mathrm{KH}_{2} \mathrm{PO}_{4}$ containing $0.5 \mu \mathrm{M}$ o-CA, followed by enzyme assay at constant $\mathrm{pH}$. Panel $\mathrm{B}$ : Protection by $1 \mathrm{mM}$ TNBS against the o-CA-induced inactivation of $B$. cereus collagenase. The modification mixture was as in Fig. $1 \mathrm{~A}$, but involved several additions of o-CA (arrows) to ascertain the presence of active reagent.

hydroxylamine at $\mathrm{pH} 7.0$ followed by thorough dialysis, did not alter the spectra, and no reactivation of the enzymes took place.

The values of $\mathrm{K}_{\mathrm{m}}$ and $\mathrm{V}_{\max }$ in the hydrolysis of PZ-PLGPA were studied using $B$. cereus collagenase (Table $I$ ). $K_{m}$ increased with increasing degree of inactivation, suggesting that perhaps an active site substrate-binding group was affected. The native and fully inactivated collagenases were hydrolyzed for amino acid analyses. Treatment of the $\underline{B}$. cereus and $\underline{c}$. histolyticum

Table 1. Effect of o-CA treatment of the $\underline{B}$. cereus collagenase on $\mathrm{K}_{\mathrm{m}}$ and $\mathrm{V}_{\mathrm{max}}$ in the hydrolysis of PZ-PLGPA. The enzyme was inactivated in the presence of o-CA to the activity levels indicated. As a control, native enzyme was used. The constants were determined according to the double-reciprocal plot.

\begin{tabular}{|c|c|c|c|c|}
\hline & Enzyme activity & $\mathrm{K}_{\mathrm{m}}$ & $(\bmod i f i e d)$ & $v_{\text {max }}(\operatorname{modified})$ \\
\hline$\mu \mathrm{M}$ & remaining $(z)$ & $\overline{\mathrm{K}_{\mathrm{m}}}$ & (control) & $\bar{V}_{\max }($ control) \\
\hline $\begin{array}{l}0 \\
0.5 \\
1.0 \\
2.5\end{array}$ & $\begin{array}{r}100 \\
75 \\
43 \\
5\end{array}$ & & $\begin{array}{l}1.00 \\
0.94 \\
2.69 \\
5.92\end{array}$ & $\begin{array}{l}1.00 \\
0.41 \\
0.46 \\
0.26\end{array}$ \\
\hline
\end{tabular}


collagenases with ㅇ-CA destroyed at least one tyrosyl residue. other amino acids were not significantly affected.

DISCUSSION: Previous literature has laid the main stress on the reactions of the CAs with amino groups. Excepting one preliminary note (15), there has been no information about the use of $\underline{0}-\mathrm{CA}$ as an enzyme inactivator. ㅇ-BQ was reported to modify about three out of the six tryptophyl residues present in lysozyme but only at highly acidic pH values (21) and at relatively high (e.g. $2 \mathrm{mM}$ ) concentrations. Because the enzyme inactivations studied by us appeared at and above physiological $\mathrm{pH}$ values in the presence of very low concentrations of a tetrachloro derivative of $\underline{0}-\mathrm{BQ}$, it is likely that quite different mechanisms and possibly different target groups in proteins were involved in these cases.

Quinones like o- $\mathrm{CA}$ have been used as dehydrogenation reagents of hydroaromatic compounds (22) whereby the quinones selectively abstract hydrogen from the latter. DDQ, a powerful quinone reagent in routine use (22), oxidizes 1,2dihydronaphthalene 5,500 times faster than $\mathrm{p}-\mathrm{CA}$ at $100^{\circ} \mathrm{C}$, while o- $C A$ reacts 4,200 times faster than $\mathrm{p}-\mathrm{CA}$. The greater reactivity of o- $\mathrm{CA}$ compared to $\mathrm{p}-\mathrm{CA}$ may result from strong hydrogen bonding in the transition state leading to a catecholate monoion (23). In this study, 으-CA was a much stronger enzyme inactivator than DDQ or $p-C A$.

It is possible that o-CA anion radicals constitute the effective inhibitory species which react, in addition to hydroaromatic groups, also with amino groups. The inactivation of the collagenases took place at an almost stoichiometric ratio of 으-CA to enzyme, speaking for a specific active site-directed reaction. Bacterial collagenase activity depends on the involvement of an active tyrosyl residue, an active carboxyl 
group and an active lysyl residue as well $(16,24,25)$. The results presented here and the nature of the collagenase active site suggest that either the tyrosyl or the lysyl residue reacted with o-CA. Amino acid analyses showed that only tyrosyl residues were affected. Although 으스 reacts with amines, the reactions are slow (5) compared with the extremely high velocity of dehydrogenation of polycyclic hydroaromatic compounds (22). The inactivation caused by $\underline{O}-\mathrm{CA}$ was a very rapid process and may have involved a similar hydrogen abstraction from an active site (dissociated) tyrosine as with polycyclic compounds (22).

TNBS has been used as a reagent of protein amino groups (1820). The protection by TNBS against o-CA-induced enzyme inactivation may have resulted from the protection of an active site $\varepsilon$-amino group. TNBS also blocks SH-groups (26), but these enzymes do not have active sH-groups $(16,24)$. The bulky reaction product so formed may have prevented o-CA from attacking the active tyrosyl residue. TNBS may also have protected the enzyme by reacting directly with o-CA. Although it will be necessary to verify these ideas with other enzymes in more detailed studies, the near stoichiometry of the reaction suggests that only one active site group was the target of o-CA attack. These results showed that o-CA can be used as a very fast, irreversible inactivator of microbial collagenases, completing the list of strong collagenase inhibitors previously described $(27,28)$.

ACKNOWLEDGEMENT: Supported by NIDR Grant DE02731.

\section{REFERENCES:}

1. Briegleb, G. (1964) Angew. Chem. (International Edition in English) 3, 617-632.

2. Weitz, E. (1954) Angew. Chem. 66, 658-677.

3. Feigl, F. (1966) Spot Tests in Organic Analysis, 7 th ed., pp. 249, 407, Elsevier, Amsterdam. 
4. Feigl, F., Gentil, V. and Stark-Mayer, C. (1957) Microchim. Acta 3-4, 342-353.

5. Al-Sulimany, F. and Townshend, A. (1973) Anal. Chim. Acta $66,195-199$.

6. Al-Ghabsha, T.S., Rahim, S.A. and Townshend, A. (1976) Anal. Chim. Acta 85, 189-194.

7. Korany, M.A. and Wahbi, A.M. (1979) Analyst $104,146-148$.

8. Wahbi, A.M., Mohamed, M., Abounassif, M. and Gad-Kariem, E. (1985) Anal. Letters 18(B3), 261-267.

9. Wahbi, A.M., Lofti, E.A. and Aboul-Enein, H.Y. (1984) Talanta $31,77-78$.

10. Martynenko, F.P. (1977) Ukr. Biochim. Z. 3, 121-125 (in Russian).

11. Birks, J.B. and Slifkin, M.A. (1963) Nature 197, 42-45.

12. Slifkin, M.A. (1964) Spectrochim. Acta 20, 1543-1554.

13. Lin, B.Y. and Cheng, K.L. (1980) Anal. Chim. Acta 120, 335345 .

14. Mulliken, R.S. (1952) J. Am. Chem. Soc. 74, 811-824.

15. Dierickx, P.J. (1983) Res. Comm. Chem. Path. Pharm. 41, 517520.

16. Makinen, K.K. and Makinen, P.-L. (1987) J. Biol. Chem. 262, 12488-12495.

17. Wunsch, E. and Heidrich, H.G. (1963) Hoppe-Seyler's Z. Physiol. Chem. 333, 149-151.

18. Means, G.E., Congdon, W.I. and Bender, M.L. (1972) Biochemistry $11,3564-3571$.

19. Ting, L.-P. and Wang, J.H. (1981) Biochem. Biophys. Res. Comm. 101, 934-938.

20. Satake, K., Okuyama, T., Ohashi, M. and Shinoda, T. (1960) J. Biochem. 47, 654-660.

21. Narasimhan, S. and Vithayathil, P.J. (1987) Ind. J. Biochem. Biophys. 24, 146-152.

22. Fu, P.P. and Harvey, R.G. (1978) Chem. Rev. 78, 317-361.

23. Braude, E.A., Brook, A.G. and Linstead, R.P. (1954) J. Chem. Soc., 3569 .

24. Bond, M.D., steinbrink, D.R. and Van Wart, H.E. (1981) Biochemistry 23, 3092-3099.

25. Bond, M.D., Steinbrink, D.R. and Van Wart, H.E. (1981) Biochem. Biophys. Res. Comm. 102, 243-249.

26. Kotaki, A., Harada, M. and Yagi, K. (1964) I. Biochem. 55, 553-561.

27. Galardy, R.E. and Grobelny, D. (1983) Biochemistry 22, 45564561.

28. Yiotakis, A. and Dive, V. (1986) Eur. J. Biochem. 160, 413418 . 